\title{
Components of Savings Accumulation in Nigeria: An Empirical Evidence
}

\author{
Ogbodo, Chinedu Joel \\ Department of Economics, University of Nigeria, Nsukka \\ chinedu.ogbodo172657@unn.edu.ng
}

Phone: $+\mathbf{2 3 4 7 0 6 4 4 0 9 3 5 0}$

\begin{abstract}
The paper investigated the components of savings accumulation in Nigeria over the period 1980 to 2017. Secondary data were collated from World Development Index (WDI). In evaluating the objectives, the study employed the Auto Regressive Distributive Lag (ARDL) and Vector Error Correction Model (VECM) estimation methods. The key findings of the study show that the components of savings identified in literature understudied in the paper specifically, GDP per capita, foreign direct investment, financial deepening, interest rate, inflation rate exchange rate significantly influence savings accumulation in Nigeria either in short run, long run or both. Financial deepening was found statistically significant but influences savings negatively. Inflation rate was statistically insignificant although negative. The result from the VECM causality test revealed that short run and long run causal relationship exist between savings and the afore mentioned components in Nigeria. Hence, the study recommends careful manipulation of the identified savings components in a manner that they will not yield a counterproductive result in the economy rather contribute to the growth of savings and ultimately, the growth of Nigeria economy as a whole. It further recommends that the Nigerian government through its financial institutions encourage savings from both small and big savers which to large extent will assuage the perceived undeserved influence of financial deepening on savings accumulation.
\end{abstract}

Key Words: Savings Accumulation, Components of Savings; Financial Deepening; ARDL; VECM

\section{Introduction}

The issue about savings and what motivates it in different economies of the world has continued to generate a long standing argument among researchers and policy makers. A noticeable increase in savings accumulation has occurred in most economies of the South-East Asia for more than three and half a decade from now. But disappointingly, a significant stagnation or rather a decline in savings was noticed for countries in the Sub Saharan Africa, Latin America and the Caribbean (Loayza, 2000).

In Nigeria, there exist a wide discrepancy between the economy's income level and savings rate owing to the difficulties in assessing the revenue which emanates from sales of the economy's resources such as the crude oil and other primary products that the country exports to the rest of 
the world; this has resulted to reduction in investment and then short fall in savings and capital accumulation. As been one of the leading economies in Africa and aiming to be among the twenty five leading economies of the world by the year 2025 it is unarguably that Nigeria must be on the path of fast and sustainable increase in savings for investment and hence growth. There is a clear evidence that savings in Nigeria is at the downward side; savings mobilization from the rural areas are a far cry due to the poor saving culture of residents. Significantly to the poor mobilization of savings is the nature and structure of the economy. The Nigeria economy is heavily dependent on revenue generated from sales of agricultural products and hence it is needless to argue that income flow is quite irregular, unpredictable and seasonal which discourages savings or leads to inadequate response to savings. Savings gives the less developed countries the opportunity to invest which improves economic growth. Increase in savings leads to increase in capital formation and production activities that lead to employment creation and reduce external borrowing of government. Low domestic saving rates may maintain low-growth levels as stated by Harrod Domar model which suggests that savings is a crucial component to be considered for economic growth. Sourcing for fund externally has its own tradeoff which might be detrimental to growth. In line with this argument Malunond (2007) opined that depending on foreign sources to financed investment makes the country highly sensitive to external shocks. Based on this, accumulation of savings remains a priority for investment financing so as to reduce the adverse effect associated with external economic fluctuations.

\subsection{Trend of Savings accumulation in Nigeria from 1980 to 2017}

The trend of savings in Nigeria has shown that private and public savings have not had a robust upward movement overtime. This could be largely due to the saving culture of the country's residents, poor saving orientation, attitude of the financial institutions which do not encourage savings like situations where most banks target big customers and government deposits paying little or no attention to the small savers not knowing that the funds from household savings are relatively cheaper and more stable than government deposits which is mostly volatile and expensive; and fiscal indiscipline among the public office holders. In line with this view Nnanna, Englama and Odoko (2004) stated that the level of funds mobilisation by banks is quite low because of poor banking habit of the people. According to the authors, there is no incentive to funds mobilisation which is unconnected to the attitude of banks to small savers. 
Data from the National Bureau of Statistics (NBS) (2017) and Central Bank of Nigeria (CBN) (2017) reveals an unsteady growth of savings accumulation from 1980 to 1985; it was mostly characterized by downward movements. Within this period gross national savings which comprises of public savings and savings from citizen within the country and abroad was about $0.06 \%$ of the country's income. From $1985-1989$ savings showed a little increase of about $0.4 \%$, and between 1990 and 1994 the gross national savings reduced significantly to $0.3 \%$, and within the period 1995 to 1999 it rose again to 1.6\%, during the period 2000-2004 national savings moved up to $7.6 \%$, between 2005 and 2009 savings declined dramatically by $7.2 \%$, during the period 2010-2014 domestic private savings increased to 32.7\%. From 2014 to 2016 the national savings declined to significantly by $15.1 \%$ from $32.7 \%$. Between 2016 and 2017 it deteriorated further to $11.6 \%$. These showed that there has not been a record of the desired growth in savings. Unfortunately, in the face of these persistence decline in savings the country's GDP has maintained an upward movement. For instance between 1980 and 1985 the national income was about 17.3 trillion and during the period of 1985-1989 it increased to 17.5 trillion and in 1990-1994 it also increased to 20.2 trillion, from 1995-1999 it rose to 22.5 trillion, while from 2000-2004 it moved up to 37.9 trillion. In 2005-2009 the income increased to 51.4 trillion, between 2010 and 2014 the income rose to 68 trillion. From 2014 to 2017 the income increase to 70.12 trillion. From the foregoing there still exist significant gap between the level of income and the national savings.

\subsection{The Problem}

Classical economists hold the view that savings are dependent upon income. Adam Smith in his work showed that savings always equals investment which is a component of income, hence, any increase in income increases savings. (Obadan and Odusola, 2001; Athukorala and Sen, 2004) argued that strong relationship exist between savings, investment and growth. The poor growth recorded by most developing economies has been an issue of serious concern to economists as was earlier stated. That of Nigeria is no a mere issue to be disregarded as the economic growth recorded over the years is nothing to be compared with the level of investment or savings. The savingincome gap has been linked with some undeserved economic, social and political anomalies. For

instance, the Nigeria economy saw a tremendous increase in income from early 1970s to early 1980s which was not unconnected to the oil boom accompanied by an investment boom particularly in the public sector. However, investment fell with the collapse of the global market for crude oil within the $80 \mathrm{~s}$, this was followed by a sharp decline in economic growth. National 
income was between $9.5 \%$ and $8.9 \%$ from 1980 to 1985 . The rise in oil prices during the 80 s was supposed to push up investment and hence savings. Unfortunately, this was untrue about Nigeria because the windfall income was mostly spent by the government who decided how the income was to be used. The then military government was characterized by inexperienced leaders whose decisions were to a large extent inadequate and incompetent; this was also accompanied by a high degree of wastages.

The structural adjustment programme of 1986 was incorporated to remedy the situation. The idea behind this was to have a stable macroeconomic and investment environment that could encourage better savings accumulation. In order to achieve this feat interest rates which used to be fixed were replaced by an interest rate regime driven by domestic forces. This policy change reduced emphasis on stimulating investment through low interest rates and encouraged mobilization of savings through the uncontrolled actions of market forces on interest rates. Nonetheless, the goal of increased savings was not realized as the investment could not rise to anything near the level it reached during the 70 s. Efforts by successive government to deepen the financial sector, raise savings and investment were met with failure owing to continuous upward review of projected expenditure, overemphasis on public investment, incessant disequilibrium in plans implementation, corruption, bad coordination, inconsistencies and overdependence on crude oil revenue.

Available data from the CBN (2017) shows that the saving culture in Nigeria is very poor relative to other developing economies and the level of savings is in no way commensurate to the upward growth witnessed in the national income. For instance, the windfall income of the early 1970s, 1980s, 2000s, 2010 to 2014 that made the country to witness a robust growth of about $5.8 \%$ within these periods (CBN, 2015). Nevertheless these windfall income could not translate to increased savings. From the foregoing, the question remains what exactly motivates savings in Nigeria given such an incommensurate growth in savings vis-à-vis growth in income. Although attempts have been made by empirical works to unearth some aspects of savings behavior. Notwithstanding, there are still relevant puzzles regarding some observed policies in spurring growth in savings yet not addressed. It is plausible to ponder about the efficacy of some pro-growth policies such as macroeconomic stability and higher income growth in bringing about the desired increment in the level of savings; how effective is the financial sector development in boosting savings? Can there 
be any possible improvement in the level of national savings if fiscal policy is manipulated in the form of an increase or decrease in in public spending? These and probably other puzzles are left for policy makers to jostle.

\subsection{Objectives}

The broad objective of this paper is to investigate the components of savings accumulation in Nigeria. Specifically, the paper is embodied by three objectives:

1. Estimation of long run and short run causal relationship between savings accumulation and its components in Nigeria.

2. Investigation of the relationship between savings accumulation and its components in Nigeria.

3. Evaluation of the influence of financial deepening on savings accumulation in Nigeria.

\subsection{Review of Theories}

\subsubsection{Life Cycle Hypothesis}

The Life-cycle hypothesis was developed by Franco Modigliani in 1957. The theory states that individuals desire to even out consumption throughout their lifetime. These individuals borrow when their income is inadequate and then save as their income rises. The LCH model sees savings to depend on the desire to have wealth to pass on and be better off during times of little or no income (which can be termed difficult times). It assumes that Younger individuals tend to save nothing and in the worst case borrow which could be termed negative saving. This can be linked to relatively low income coupled with debt incurred to fund education, purchase of homes amongst other expenses. However, in the mid of the life cycle, it is expected that savings of the individual as he offsets debt and saves for retirement to become positive. For example, for a student, it is plausible to borrow in order to acquire educational certificates or better still borrow to finance education. Afterwards, as one secures a job and continues to work with inflow of income he repays the student loan, from that time he begins to save in order to keep up with the level of consumption during retirement. It follows that the accumulated savings provides the saver the privilege of maintaining and enjoying the same level of income after the expiration of the working age. The theory suggests that wealth in form of savings accumulates at working age owing to a continuous flow of income, however the accumulated savings gets depleted during retirement. Hence the 
theory points out that the accumulation of savings for retirement is the motivation for foregoing present consumption.

\subsubsection{Permanent Income Hypothesis}

Milton Friedman developed the permanent income hypothesis in his 1957 book A Theory of the Consumption Function. As classical Keynesian consumption theory was unable to explain the constancy of savings rate in the face of rising real income. It supposes that a person's consumption at a point in time is determined not just by their current income but also by their expected income in future years, their "permanent income". In its simplest form, the hypothesis states that changes in permanent income, rather than changes in temporary income, are what drive the changes in a consumer's consumption patterns. Its predictions of consumption smoothing, where people spread out transitory changes in income over time, departs from the traditional Keynesian emphasis on the marginal propensity to consume. It has had a profound effect on the study of consumer behavior, and provides an explanation for some of the failures of Keynesian demand management techniques.

\subsubsection{Financial Liberalization Theory}

In 1973, Ronald McKinnon and Edward Shaw came up with the argument that savings is a function interest rate thereby challenging the then renown theoretical position. McKinnon and Shaw viewed developing economies as being financially repressed. Their central argument is that financial repression is a form of indiscriminate distortions of financial prices including interest rates and foreign-exchange rates according to Fry (1995). In other words, financial repression is a combination of heavy taxation, interest rate controls and government participation in the credit allocation process will most likely lead to both a decrease in the depth of the financial system and a loss of efficiency, with which savings are intermediated (Sen and Vaidya, 1997). However they argued that financial liberalization tends to raise ratios of domestic private savings to income (Shaw, 1973). Therefore, financial liberalization will lead to significant economic benefits through a more effective domestic saving mobilization, financial deepening and efficient resource allocation. The core argument of the McKinnon-Shaw thesis where savings are assumed to be positively related to the real rate of interest.

\subsection{Empirical Reviews}


In Kenya Tiriongo (2005) studied the determinants of aggregate domestic private savings over the period 1980 to 2003 using Ordinary Least Square procedure. The study was motivated by the existence of substantial fluctuations in the ratio of aggregate domestic private savings to GDP. The study found that aggregate private savings in Kenya were significantly determined by the current account deficit, the ratio of M2 money to GDP, real gross per capita income growth, deposit rate and the old age dependency ratio.

To examine the key determinants of domestic savings in South Africa, Odhiambo (2007) employed the cointegration based error-correction model. The study was motivated by the current low and declining saving rate in South Africa. The empirical results of this study, which cover the period 1968-2004, indicate that savings in South Africa are largely determined by the growth rate of real GDP, foreign savings, real deposit rate, government expenditure and terms of trade.

To analyze the determinants of the household saving rate for China from 1995 to 2004 Horioka (2007) used panel data. The result showed that income growth rate, inflation rate, and real interest rate were found to be important determinants of saving rates in China over the period under consideration. These findings provide support for the life cycle hypothesis as well as the permanent income hypothesis.

Kudaisi (2013) studied the determinants of domestic savings in West Africa during 1980-2006 anchored on Hall hypothesis of consumption and found that the dependency ratio and interest rate had negative and insignificant effects on domestic savings, the GDP growth rate had positive and statistically insignificant effect, while the government budget surplus and inflation rate were statistically significant determinants of savings.

Epaphra (2014) examined the factors affecting savings in Tanzania over the 1970-2010 period using time series data and Granger Causality test and found that real GDP growth rate, as well as the disposable income, life expectancy and population growth had positive impact on savings in Tanzania while inflation had a negative impact.

Wafure (2012) used co-integration and Error Correction Mechanism to determine the relationship between financial sector reforms and private savings in Nigeria. The estimated results showed that lagged value of private savings, consumer price index, savings deposit rate, Income per capita showed a significant and inverse impact on private savings while financial liberalization and 
income growth have direct and significant impact on private savings but wage rate and foreign savings were insignificant.

Olayemi and Jolaosho (2013) empirically assessed the impact of real interest rate on savings mobilization in Nigeria. The Vector- Auto Regression (VAR) was employed, using the time series data from 1980 to 2008 . The author reported that real interest rate has negatively impacted on the level of savings mobilization in Nigeria. They concluded that there is need for government in Nigeria to bridge the existing gap between the lending and savings rates and increase per capita income level of the populace, to stimulate savings for investment and economic growth. Imoughele and Ismaila (2014) evaluate the determinant of private savings in Nigeria from 1981 to 2012 using cointegration and Error Correction Mechanism. The results show that income per capital, inflation rate, term of trade and financial deepening are significant determinants of private savings in Nigeria. The study recommended that there is need for proper financial market development and government should retain tight monetary and fiscal policies in order to fight inflation in the Nigerian economy. Finally, Government expenditure should be tied to specific viable economic projects in the economy.

Elom-Obed, Odo, Udude and Okonkwo (2016) examined the determinants of private domestic savings in Nigeria from 1980 to 2015, using data obtained from CBN and IMF-IFS. The econometric analytic tools used are, cointegration test, vector error correction model, Granger causality test. The results showed a stable long run relationship between the variables. The study recommends conscious policy aimed at reducing the cost of living of the people, so that the part of disposable income spent on social services will reduce thereby increasing domestic private savings.

In the study to ascertain the determinants of private savings in Nigeria between 1970 and 2007, Nwachukwu and Odigie (2009) utilized Error-correlation technique and found that the saving rate rose together with both the growth rate of disposable income and the real interest rate on bank deposits. The study also found that public saving tends not to overcrowd private saving suggesting that government policies directed at increasing fiscal balance had the capacity to bring about a considerable increase in the national saving rate; while the degree of financial depth had a negative but insignificant impact on saving behavior in Nigeria.

Using time series data for Nigeria over the period 1970 to 2010, Nwachukwu (2012) studied private saving based on co-integration procedures within the framework of the Life Cycle 
Hypothesis. The author found that the saving rate increased with both the real interest rate on bank deposits and the growth rate of disposable income whereas financial debt had an adverse effect on saving behaviour in Nigeria.

\subsection{Methodology}

In the preceding section of this study some theories on savings were reviewed. It was found that most of the studies that have been done on savings either on individual country basis or group of countries adopted the theory of Life Cycle Hypothesis. These studies include: Collins (1991); Chete (1999); Elbadawi and Mwega (2000); Massion Boyoumi and Sameii (1998); Ozcan (2006); Elom-Obed et al. (2016) and others. However, a review of literatures on determinants of savings showed that Life Cycle hypothesis alone cannot provide adequately a theoretical basis due to the fact that LCH cannot capture all the determinants of savings. This study therefore adopts the lifecycle/permanent-income hypothesis developed by Hall (1978). The theory combines the lifecycle and permanent income variables used in this study. Other variables to be included in the model can be explained through the Keynesian macroeconomic framework and the McKinnon-Shaw financial liberalization theory.

\subsection{Model specification}

\section{Model 1 for objective 1:}

Causal relationship between savings and its determinants in Nigeria: the study employs the Vector Error Correction Model (VECM) to estimate the short run and long run causal relationship between savings and its determinants. To achieve this, the following functional relationship is specified;

$\ln S a v=f(\ln P C G D P, F i n D E P, \ln F D I, I N T R, I N F, \ln E X C H)$.

Where:

Sav=Savings (proxy by gross national savings); PCGDP=Income Per Capita; FinDEP= Financial deepening (ratio of M2 to GDP); FDI=Foreign Direct Investment; INTR=Interest Rate; INF= Inflation Rate; $\mathrm{EXCH}=$ Exchange rate; 1 =Natural Logarithm 
In order to accomplish objective 1 above, the following VECM equation shall be specified;

$$
\begin{aligned}
& \Delta \ln S a v_{t}=\sum_{i=1}^{p} \alpha_{i} \Delta \ln S a v_{t-i}+\sum_{i=1}^{p} \lambda_{i} \Delta \ln P C G D P_{t-i}+\sum_{i=1}^{p} \pi_{i} \Delta F i n D e p_{t-i}+\sum_{i=1}^{p} \phi_{i} \Delta \ln F D I_{t-i}+\sum_{i=1}^{p} \gamma_{i} \Delta I N T R_{t-i}+\sum_{i=1}^{p} \sigma_{i} \Delta I N F_{t-i}+\sum_{i=1}^{p} \vartheta_{i} \Delta \ln E X C H_{t-i}
\end{aligned}
$$

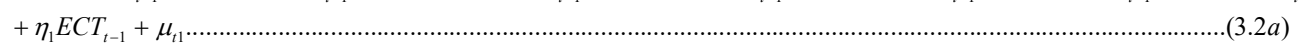

$$
\begin{aligned}
& \Delta \ln P C G D P_{t}=\sum_{i=1}^{p} \lambda_{i} \Delta \ln P C G D P_{t-i}+\sum_{i=1}^{p} \pi_{i} \Delta \ln \operatorname{Sav}_{t-i}+\sum_{i=1}^{p} \alpha_{i} \Delta \operatorname{FinDep}_{t-i}+\sum_{i=1}^{p} \phi_{i} \Delta \ln F D I_{t-i}+\sum_{i=1}^{p} \gamma_{i} \Delta I N T R_{t-i}+\sum_{i=1}^{p} \sigma_{i} \Delta I N F_{t-i}+\sum_{i=1}^{p} \vartheta_{i} \Delta \ln E X C H_{t-i}
\end{aligned}
$$

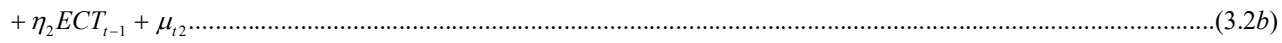

$$
\begin{aligned}
& \Delta \text { FinDep }_{t}=\sum_{i=1}^{p} \pi_{i} \Delta \text { FinDep }_{t-i}+\sum_{i=1}^{p} \alpha_{i} \Delta \ln \operatorname{Sav}_{t-i}+\sum_{i=1}^{p} \lambda_{i} \Delta \ln P C G D P_{t-i}+\sum_{i=1}^{p} \phi_{i} \Delta \ln F D I_{t-i}+\sum_{i=1}^{p} \gamma_{i} \Delta I N T R_{t-i}+\sum_{i=1}^{p} \sigma_{i} \Delta I N F_{t-i}+\sum_{i=1}^{p} \vartheta_{i} \Delta \ln E X C H_{t-i}
\end{aligned}
$$

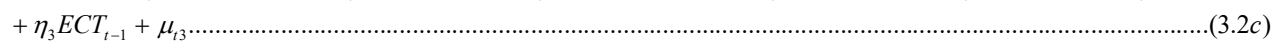

$$
\begin{aligned}
& \Delta \ln F D I_{t}=\sum_{i=1}^{p} \pi_{i} \Delta \ln F D I_{t-i}+\sum_{i=1}^{p} \alpha_{i} \Delta \ln \operatorname{Sav} v_{t-i}+\sum_{i=1}^{p} \lambda_{i} \Delta F i n D e p_{t-i}+\sum_{i=1}^{p} \phi_{i} \Delta \ln P C G D P_{t-i}+\sum_{i=1}^{p} \gamma_{i} \Delta I N T R_{t-i}+\sum_{i=1}^{p} \sigma_{i} \Delta I N F_{t-i}+\sum_{i=1}^{p} \vartheta_{i} \Delta \ln E X C H_{t-i}
\end{aligned}
$$

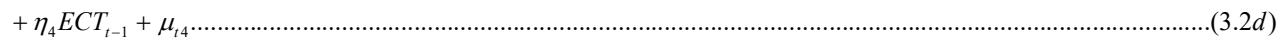

$$
\begin{aligned}
& \Delta I N T R_{t}=\sum_{i=1}^{p} \pi_{i} \Delta I N T R_{t-i}+\sum_{i=1}^{p} \alpha_{i} \Delta \ln \operatorname{Sav}_{t-i}+\sum_{i=1}^{p} \lambda_{i} \Delta \ln P C G D P_{t-i}+\sum_{i=1}^{p} \phi_{i} \Delta F i n D e p_{t-i}+\sum_{i=1}^{p} \gamma_{i} \Delta \ln F D I_{t-i}+\sum_{i=1}^{p} \sigma_{i} \Delta I N F_{t-i}+\sum_{i=1}^{p} \vartheta_{i} \Delta \ln E X C H_{t-i}
\end{aligned}
$$

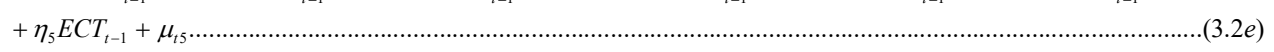

$$
\begin{aligned}
& \Delta I N F_{t}=\sum_{i=1}^{p} \pi_{i} \Delta I N F_{t-i}+\sum_{i=1}^{p} \alpha_{i} \Delta \ln \operatorname{Sav}_{t-i}+\sum_{i=1}^{p} \lambda_{i} \Delta \operatorname{FinDep}_{t-i}+\sum_{i=1}^{p} \phi_{i} \Delta \ln P C G D P_{t-i}+\sum_{i=1}^{p} \gamma_{i} \Delta \ln F D I_{t-i}+\sum_{i=1}^{p} \sigma_{i} \Delta I N T R_{t-i}+\sum_{i=1}^{p} \vartheta_{i} \Delta \ln E X C H_{t-i}
\end{aligned}
$$

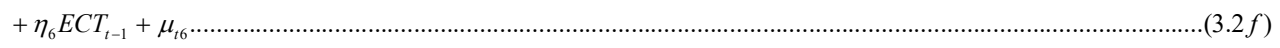

$$
\begin{aligned}
& \Delta \ln E X C H_{t}=\sum_{i=1}^{p} \pi_{i} \Delta \ln E X C H_{t-i}+\sum_{i=1}^{p} \alpha_{i} \Delta \ln \operatorname{Sav}_{t-i}+\sum_{i=1}^{p} \lambda_{i} \Delta \text { FinDep }_{t-i}+\sum_{i=1}^{p} \phi_{i} \Delta \ln P C G D P_{t-i}+\sum_{i=1}^{p} \gamma_{i} \Delta \ln F D I_{t-i}+\sum_{i=1}^{p} \varpi_{i} \Delta I N T R_{t-i}+\sum_{i=1}^{p} \vartheta_{i} \Delta \ln I N F_{t-i}
\end{aligned}
$$

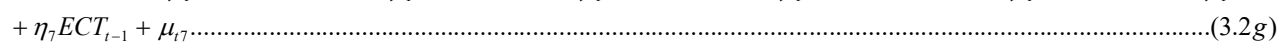

The VECM specified above possesses relevant information about the short run and long-run adjustment to changes in the independent variables. $\Delta$ is the first difference operator; $\pi_{i}, \alpha_{i}, \lambda_{i}$, $\phi_{i}, \gamma_{i}, \varpi_{i}$ and $\vartheta_{i}$ are short run parameters. The symbols $\eta_{1}$ to $\eta_{7}$ and $\mu_{1}$ to $\mu_{7}$ are the long run (vector of the error correction) parameters and residual terms respectively. $\mathrm{ECT}_{\mathrm{t}-1}$ is the one period lagged error-correction term derived from co-integration equation. The Akaike Information Criterion (AIC) determines the optimal lag length $p$. $l n$ indicates natural logarithm. The residuals $\mu_{t i}$ are assumed to be normally distributed with zero mean and constant variance.

\section{Model 2 for objectives 2 \& 3:}

Modeling the relationship between savings and its components; and evaluation of the influence of financial deepening on savings in Nigeria. In order to achieve objectives $2 \& 3$ above a modified multiple variables regression model is specified to suit the Nigerian economy. The functional form of the model is specified thus:

$\ln S a v=f(\ln P C G D P$, FinDep $, \ln F D I, I N T R, I N F, \ln E X C H)$.

Transforming equation 3.2.1 to econometric form, we have:

$\ln \mathrm{Sav}_{t}=\beta+\delta_{1} \ln P C G D P_{t}+\delta_{2} \mathrm{FinDep}_{t}+\delta_{3} \ln F D I_{t}+\delta_{4} I N T R_{t}+\delta_{5} I N F_{t}+\delta_{6} \ln E X C H_{t}+\psi_{t}$

Where: 
$\beta=$ intercept; $\delta_{1}>0 ; \delta_{2}>0 ; \delta_{3}>0 ; \delta_{4}<0 ; \delta_{5}>0 ; \delta_{6}<0$ are the coefficients of the regressors; while $\psi=$ error term. However, this study employs the autoregressive distributed lag (ARDL) bounds test approach due to Pesaran, Shin and Smith (2001) this is because most macroeconomic variables do not instantaneously transmit to other variables (Keynes, 1936). The basic assumption underlying the ARDL model is that the regressors are uncorrelated with the error term. The model also assumes that variables are stationary at level form or at least after first difference. Hence, the study specifies a dynamic model:

$\Delta \ln \operatorname{Sav}_{t}=\omega_{0}+\pi_{1} \ln S a v_{t-1}+\pi_{2} \ln P C G D P_{t-1}+\pi_{3}$ FinDep $_{t-1}+\pi_{4} \ln F D I_{t-1}+\pi_{5} I N T R_{t-1}+\pi_{6} \ln F D I_{t-1}+\pi_{7} I N F_{t-1}+\pi_{8} \ln E X C H_{t-1}$

$+\sum_{i=1}^{p} \alpha_{i} \Delta \ln S a v_{t-i}+\sum_{i=1}^{p} \lambda_{i} \Delta \ln P C G D P_{t-i}+\sum_{i=1}^{p} \phi_{i} \Delta$ FinDep $_{t-i}+\sum_{i=1}^{p} \delta_{i} \Delta \ln F D I_{t-i}+\sum_{i=1}^{p} \theta_{i} \Delta I N T R_{t-i}+\sum_{i=1}^{p} \beta_{i} \Delta I N F_{t-i}+\sum_{i=1}^{p} \chi_{i} \Delta \ln E X C H_{t-i}$

$+\rho_{t}$

Where:

$\pi_{\mathrm{i}}=$ long run parameters; and $\alpha, \lambda, \phi, \delta, \theta, \beta, \psi$ and $\chi$ are coefficients of the short-run parameters. $\Delta=$ first difference operator; $l n=$ natural logarithm of the variables; $p=$ optimal lag length selected by Akaike's Information Criterion (AIC) and $\rho=$ white noise error term assumed to be normally distributed.

\subsection{Model Estimation Procedure, Justification and Data}

As earlier indicated, the paper utilizes the vector error correction model (VECM) and autoregressive distributive lag (ARDL) model accordingly. Prior to estimation, the test for unit root in order ascertain the order of integration is conducted employing the Augmented DickeyFuller (ADF) test. If the variables are found to be integrated of same order, the Johansen method of cointegration will be conducted to ascertain the number of co-integrating vector(s). However, if the variables are integrated of different orders, say I(0) and I(1) then the ARDL Bounds Test of cointegration is utilized to ascertain the existence of a long run relationship; in case the variables are cointegrated then the VECM is estimated as specified above. The VECM has the capacity to estimate both the long run and short run direction of causality. In addition, post estimation diagnostic checks such as will also be carried out. Other measures which follow after estimation include serial correlation test, heteroscedasticity test and normality test are carried out to ensure consistency with the assumptions of the models and guarantee reliability of results for policy prescription. The study utilizes secondary data sourced from World Bank's World Development Indicators 2018 online database covering the period 1980 to 2017. 


\section{Presentation and Analysis of Results}

\subsection{Unit root test}

For this purpose, the Augmented Dickey-Fuller test is used. It follows that a variable is stationary if the absolute ADF value of Test statistics is greater than any of the absolute test critical values. The following results were obtained and reported in the table below accordingly;

Table 4.1.1: ADF Unit Roots Test

\begin{tabular}{|l|l|l|c|l|}
\hline Variables & ADF Statistics & 5\% Critical values & Order of Integration & Decision \\
\hline $\ln$ Sav & -4.845493 & -3.544284 & $I(1)$ & Stationary \\
\hline $\ln \boldsymbol{P C G D P}$ & -3.805541 & -3.540328 & $I(1)$ & Stationary \\
\hline FinDEP & -4.613392 & -3.595026 & $I(1)$ & Stationary \\
\hline $\ln \boldsymbol{F D I}$ & -11.29978 & -2.945842 & $I(1)$ & Stationary \\
\hline $\boldsymbol{I N T R}$ & -5.4955 & -3.544284 & $I(0)$ & Stationary \\
\hline $\boldsymbol{I N F}$ & -5.898871 & -3.536601 & $I(1)$ & Stationary \\
\hline $\ln \boldsymbol{E X C H}$ & -5.414376 & -3.540328 & $I(1)$ & Stationary \\
\hline
\end{tabular}

Source: Researcher's Estimation using EViews

The results contained in table 4.1 above shows that all the variables are stationary after first difference, except INTR which was stationary at level.

\subsection{Co-integration test}

The ARDL Bounds Test is employed to ascertain the existence of a long run relationship. This is because the variables are integrated of different orders i.e. order zero and one. The results are contained in the table below;

Table 4.2a ARDL Bounds Test of Cointegration

\begin{tabular}{|l|c|c|}
\hline Test statistic & Value & K \\
F-Statistic & 3.830231 & 6 \\
\cline { 3 - 3 }
\end{tabular}

Critical Value Bounds

\begin{tabular}{|c|c|c|}
\hline Significance & Lower bounds I0 & Upper bounds I1 \\
\hline $10 \%$ & 2.12 & 3.23 \\
\hline $5 \%$ & 2.45 & 3.61 \\
\hline $2.50 \%$ & 2.75 & 3.99 \\
\hline $1 \%$ & 3.15 & 4.43 \\
\hline
\end{tabular}

The result in table 4.2 shows that the value of the F-Statistic, 3.830231 is greater than critical value bounds (both lower and upper) at 5\% level of significance, the study concludes that there is a long run relationship among the variables against the null hypothesis that there is no long run relationship among the variables. To affirm the above result, an error correction test for short run is conducted. The result is as displayed in table below; 
Table 4.2b ARDL Short run Test

\begin{tabular}{|l|c|c|c|c|}
\hline Variable & Coefficient & Standard Error & T-Statistics & P-Value \\
\hline CointEq(-1) & -0.798739 & 0.128108 & -6.234886 & 0.0000 \\
\hline
\end{tabular}

The CointEq(-1) term in table $4.2 \mathrm{~b}$ is the error correction term; it measures the speed of adjustment from disequilibrium (error) in the short run to reach equilibrium in the long run. The Error Correction Term coefficient (-0.798739) is negatively signed and significant. The result implies that annually about 79 percent disequilibrium is corrected to attain the long run equilibrium.

\subsection{VECM Long \& Short run causal relationship (Objective 1)}

The result of the VECM long run causal relationship (see appendix) indicates that there exists long run causality among the variables. However, for short run causality it was found that causal relationship exists only between financial deepening and inflation rate, and other variables in the model, (see appendix).

\subsection{ARDL Model Estimation for Objectives $2 \& 3$}

As it was earlier stated that the ARDL model specified in section 3 of this paper would be employed to estimate the relationship between savings and its determinants; and the influence of financial deepening on savings. The results of the estimation are presented in table 4.4 below;

Table: 4.4 the result of the ARDL Estimation

\begin{tabular}{|c|c|c|c|c|}
\hline Variable & Coefficient & Std. Error & t-Statistic & Prob.* \\
\hline LNSAV(-1) & 0.201261 & 0.128108 & 1.57103 & 0.1278 \\
\hline LNPCGDP & 1.353388 & 0.501801 & 2.697062 & 0.0119 \\
\hline LNFDI & 0.363138 & 0.130629 & 2.77992 & 0.0098 \\
\hline LNEXCH & -0.099524 & 0.195952 & -0.507903 & 0.6156 \\
\hline LNEXCH(-1) & 0.470567 & 0.204352 & 2.302724 & 0.0292 \\
\hline FINDEP & -0.01898 & 0.007227 & -2.626215 & 0.0141 \\
\hline INTR & 0.003838 & 0.021321 & 0.179996 & 0.8585 \\
\hline INTR(-1) & -0.05676 & 0.022562 & -2.515754 & 0.0181 \\
\hline INF & -0.003172 & 0.002374 & -1.336407 & 0.1926 \\
\hline C & -5.643823 & 5.323422 & -1.060187 & 0.2985 \\
\hline F-statistic & 63.39911 & $\begin{array}{c}\text { Durbin- } \\
\text { Watson stat }\end{array}$ & 1.82686 & \\
\hline Prob(F-statistic) & 0.000000 & $\begin{array}{c}\text { Adjusted R- } \\
\text { squared }\end{array}$ & 0.939758 & \\
\hline
\end{tabular}

Source: The Researcher's Estimation using EViews

\subsection{Diagnostic Tests (Post Estimation)}


Recall as well that in section 3 , it was indicated that some diagnostic checks would be carried out after estimations; this is because such tests are conducted on the error terms to ensure consistency with the assumptions of the models and guarantee reliability of results for policy prescription. These test include the serial correlation, heteroscedasticity and normality tests. The VEC Residual Heteroskedasticity and the white Heteroskedasticity Tests indicated that the error terms of individual observation have constant variance (see appendix). I.e. no problem of heteroskedasticity. The VEC Residual Serial Correlation LM Tests and Breusch-Godfrey Serial Correlation LM Test showed that the error term is not serially corrected with the dependent variable (see appendix). The VEC Residual Normality and the histogram normality test jointly show that the error terms are normally distributed (see appendix).

\section{Policy Implication of Results, Conclusion and Recommendations}

\subsection{Policy Implication of Results}

Empirical evidence from the preceding section of this study showed the existence of long run and short run relationships among the variables based on the result of the ARDL Bounds Test. The VECM long run causality tests indicated a long run causal relationship among all the variables of the model while short run causal relationship was found between savings accumulation, financial deepening and inflation rate GDP per capita, foreign direct investment, financial deepening, exchange rate, interest rate and inflation rate. It implies that the variables employed in this study contain useful information for predicting the magnitude of savings accumulation in Nigeria. The result from the ARDL estimation reveals that GDP per capita and FDI significantly and positively influences savings accumulation both in short and long run. Precisely, the result shows that savings on average increases by $13.5 \%$ and $3.6 \%$ as a result of a percentage increase in GDP per capita and FDI respectively, holding other factors fixed. Exchange rate and interest rate were found to be statistically insignificant and influence savings accumulation negatively in the short run. However, both became statistically significant and influence savings accumulation positively in the long run. Precisely, the result shows that holding other factors fixed, that on average a percentage increase in exchange rate (naira depreciation) and interest rate (inform of funds mobilization for investment) increases savings accumulation by about $4.7 \%$ and $5.6 \%$ respectively in the long run. Inflation rate although, was found to be statistically insignificant has a negative influence on savings accumulation in Nigeria. The foregoing results are consistent with works due to Loayza, et al. (2000), Agrawal et al. (2010), Sandri et al. (2012) and others who presented a 
result similar to the result obtained in this study. Financial deepening was found statistically significant but influences savings accumulation negatively in the short run; this result is consistent with the studies of Nwachukwu and Odigie (2009); and Essien and Onwioduokit (1998) for Nigeria. The authors argued that the effect of financial deepening on savings works through the expansion of the supply of credit to credit-constrained agents. However, quantitative evidence supports the theoretical prediction that financial deepening through credit expansion reduces savings as individuals are able to finance higher consumption at their current income level and hence save little or nothing. Notwithstanding, it is held in some quarters that financial deepening improves the efficiency of the financial institution intermediation and hence, investment, thus resulting in higher growth and savings as well. This implies that even though financial deepening may give agents incentives to disave it is just in the short run but in the long run growth in income due to increase in consumption will increase savings. The empirical results analyzed in this section so far point at issues critical to savings accumulation in Nigeria. It is obvious that there is a need for proper direction of a well guided policy that makes for optimal contribution of those savings components understudied in this paper, as well as policy which disincentivizes public wasteful use of resources.

\subsection{Conclusion and Recommendations}

Based on the findings of the study, it is important to argue that the components of savings accumulation identified in literature influence savings accumulation, some in the short run, long run or both as seen in the results contained in the preceding section. Hence, there is the need for a judicious and careful manipulation of those identified savings components in a manner that they will not yield a counterproductive result in the economy rather contribute to the growth of savings and ultimately, the growth of Nigeria economy as a whole. The study further recommends that the Nigerian government through its financial institutions encourage savings from both the small and big savers which to large extent will assuage the perceived undeserved influence of financial deepening on savings. Finally, it is important to point out that one thing is to accumulate savings, another thing is the proper management of the accumulated wealth, and therefore it is plausible to submit that any form of mismanagement of the accumulated savings will be counterproductive and eventually bring about a negative growth.

No conflict of interest whatsoever. 


\section{References}

Ando, A., and Franco Modigliani, (1963). The "Life Cycle" Hypothesis of Saving: Aggregate Implications and Tests. The American Economic Review, Vol. 53, No. 1, Part 1.

Kudaisi, B. V. (2013) Savings and Its Determinants in West Africa Countries. Journal of Economics and Sustainable Development .Vol.4, No.18,

Chete, L. N. (1999) Macroeconomic Determinants of Private Savings in Nigeria. NISER Monograph Series 7.

Central Bank of Nigeria (CBN) Statistical Bulletin (2017)

Elbadawi, I. A and Mwega, F. M. (2000) Can Africa's Saving Collapse Be Reversed? The World Bank Economic Review Vol 14 No.3.

Epaphra M, (2014) Empirical Investigation of the Determinants of Tanzania's National Savings, International Journal of Economic Management Science 4:213

Essien, E, and Onwioduokit (1989) Recent Developments in Econometrics: An Application to Financial Liberalization and Saving in Nigeria. NDIC Quarterly, Vol.8, No. 112.

Friedman (1957). A Theory of the Consumption Function. National Bureau of Economic Research.

Gedela, S. P. R. 2012. Determinants of Saving Behaviour in Rural and Tribal Households: An Empirical Analysis of Visakhapatnam District. International Journal of Research in Social Sciences. 2(3). 108-114.

Horioka, C. Y. and Wan, J. (2007). The determinants of Household Savings in China: A Dynamic Panel Analysis of Provincial Data. Journal of Money, Credit and Banking. 39 (8).

Husain, A. M. (1996) Private Saving and its Determinants: The Case of Pakistan. The Pakistan Development Review. 35 (1). 49-70.

Kibet, L., Mutai, B., Ouma, E., Ouma S. And Owuor, G. (2009) Determinants of Household Saving: Case Study of smallholder farmers, entrepreneurs and teachers in rural areas of Kenya. Journal of Development and Agricultural Economics. 1 (7). 137-143.

Kudaisi B.V (2013) Savings and Its Determinants in West Africa Countries, Journal of Economics and Sustainable Development. Vol.4, No.18, 2013

Loayza, N., Schmidt-Hebbel, K. and Serven, Luis. (2000) Saving in Developing Countries: An Overview. The World Bank Economic Review. 14 (3). 393-414. 
Mwega, Francis. (1997) Saving in Sub-Saharan Africa: A Comparative Analysis." Journal of African Economies. 6(3) (Supplement) 199-228.

National Bureau of Statistics (NBS) 2017 Edition

N. Loayza, K. Schmidt-Hebbel, and L. Servén (2000) Saving in Developing Countries, The World Bank Economic Review, VOL. 14, NO. 3: 393-414

Ndanshau, M.O.A (2012) On Interest Rates and other Determinants of Financial Savings: An Empirical Investigation in Tanzania. Department of Economics Working Paper Series, Vol.12, No. 5.

Nwachukwu, T. E. and Odigie P. (2009) What Drives Private Saving in Nigeria. A Paper Presented at the Centre for the Study of African Economies (CSAE) Conference, University of Oxford.

Nwachukwu, T. (2012) Determinants of Private Saving in Nigeria. Unpublished article, Africa Development Bank, Tunis. Tunisia.

Odhiambo, N. M. (2008) Interest Rates Reforms, Financial Depth and Savings in Tanzania. Savings and Development, Vol. 32, no. 2, pp 141-158.

Ogaki, M., Ostry, J. D and Reinhart, C. M (1996) Saving Behaviour in Low-and Middle-Income Developing, IMF Staff Papers 43 (March): 38-71.

Olusoji, M.O. (2003) Determinants of Private Savings in Nigeria: An Error Correction Approach. NDIC Quarterly Vol 13, pp 85-96

Özcan, K. M., A. Gunay, and S. Ertac (2003) Determinants of Private Savings Behaviour in Turkey. Applied Economics, 25 (12): 1405-1416.

Sandri, D., Ashoka, M. And Ohnsorge, F. (2012) Precautionary Savings in the Great Depression. IMF Economic Review, 60 (1).

The World Bank Group (2018) Retrieved: http://databank.worldbank.org/data//reports.aspx? Source $=2 \&$ country $=$ NIG\&series $=\&$ period $=$ Retrieved on $5^{\text {th }}$ of August, 2018

Tiriongo, K. S. (2003) Determinants of Aggregate Domestic Private Savings in Kenya, 1980-2003. Kenyatta University, Economics Department.

Uremadu, S. O. (2007) Core Determinants of Financial Savings in Nigeria: An Empirical Analysis for National Monetary Policy Formulation, International Review of Business Research Papers 3(3), 356-367. 